\title{
Comparative Study of Tubular Diameter and Quantity for Human and Bovine Dentin at Different Depths
}

\author{
Murilo Baena LOPES ${ }^{1}$ \\ Mário A. C. SINHORETI ${ }^{2}$ \\ Alcides GONINI JU'NIOR ${ }^{1}$ \\ Simonides CONSANI ${ }^{2}$ \\ John F. MCCABE ${ }^{3}$
}

\author{
${ }^{1}$ Department of Dentistry, Dental School, University of Northern Paraná, Londrina, PR, Brazil \\ ${ }^{2}$ Department of Restorative Dentistry, Piracicaba Dental School, State University of Campinas, Piracicaba, SP, Brazil \\ ${ }^{3}$ Dental Biomaterials Science Unit, School of Dental Sciences, University of Newcastle, Newcastle upon Tyne, UK
}

\begin{abstract}
This study compared the tubular dimensions and distribution of human and bovine dentin. Ten human molars and 10 bovine incisors were ground with a high-speed handpiece to obtain 3 sections at different dentin depths (superficial, middle and deep). The specimens were sputter-coated with gold to be examined under scanning electron microscopy (SEM). Three SEM micrographs were recorded randomly for each dentin depth. The number of tubules was counted and the diameter of 5 tubules selected at random was measured in each SEM micrograph. Data were analyzed statistically by ANOVA and Tukey's test $(\alpha=0.05)$. In bovine teeth, superficial dentin $(4.21 \mu \mathrm{m})$ and middle dentin $(3.98 \mu \mathrm{m})$ had a significantly greater $(\mathrm{p}<0.05)$ diameter than deep dentin $(3.14 \mu \mathrm{m})$ tubules. In human teeth, superficial dentin tubule diameter $(2.42 \mu \mathrm{m})$ was significantly smaller $(\mathrm{p}<0.05)$ than deep dentin $(2.99 \mu \mathrm{m})$ and middle dentin $(2.94 \mu \mathrm{m})$ tubule diameters, which did not differ significantly from each other $(\mathrm{p}>0.05)$. The number of tubules per square millimiter, regardless of the region, was significantly greater in human dentin $(22,329)$ than in bovine dentin $(15,964)$. There was a clear difference in tubule structure and morphology between human and bovine dentin.
\end{abstract}

Key Words: dentin, tubules, human, bovine, morphology.

\section{INTRODUCTION}

Currently, with the recent advances in dentistry, most restorative procedures involve an adhesive step. Researchers have used different substrates to simulate the clinical conditions in order to test the efficacy of adhesive materials in vitro. Human enamel and dentin are generally the substrates of choice in studies evaluating adhesive bond strength (1), but extracted human teeth are sometimes difficult to obtain for a number of reasons. Therefore, it has become necessary to consider alternative substrates. Investigators have turned to other mammalian teeth, such as bovine, ovine, equine and swine teeth, to provide sufficient amount of standardized material for their studies. These alternative substrates have been used in studies investigating caries-like lesions (2), microhardness and lesion depth studies (3) and adhesion of composite resins to enamel (4). The organic and inorganic components of bovine enamel (5) and its physical properties (6) have been investigated. Their size and availability make bovine incisors potentially useful for bond strength research (7). However, there is some concern about whether data obtained from bovine teeth can be applied to human teeth and therefore about their validity in a clinical situation (7).

Dentin is the most abundant calcified tissue in the human tooth. Located between the exterior enamel and the interior pulp, dentin is a hydrated nano-composite of hydroxyapatite mineral crystallites ( $\sim 5 \mathrm{~nm}$ thick, $\sim 45 \%$ by volume) distributed in a scaffold of type-I collagen 
fibrils ( $\sim 50-100 \mathrm{~nm}$ diameter, $\sim 30 \%$ by volume), with fluid and non-collagenous proteins making up the remaining $\sim 25 \%$ (8). Dentin microstructures and properties are the principal determinants of many procedures in restorative dentistry. Although significant progress in restorative and preventive dentistry has occurred over the past several decades based on the increased understanding of the caries process and introduction of increasingly effective bonding techniques, a key problem which remains is our lack of detailed understanding of dentin itself (9). This is because dentin is a complex hydrated biological composite structure for which only limited structure-property relationships are available (9).

The strength of the adhesive bonds formed between restorative materials and dentin is affected by the number and concentration of dentinal tubules per square millimeter and their diameter, as well as the amount of intratubular and intertubular dentin (9). It is know, for example, that more intertubular dentin is present in the crown than in the root. Schilke et al. (10) found no differences in the diameter, number or concentration of tubules in corresponding coronal dentin layers of human primary and permanent molars and bovine central incisors. A previous study reported an increase in the permeability of dentin as the depth increased (11). This was noted for both human and bovine dentin. Bovine incisor dentin had large dentinal tubules and high microporosity, which made it similar to human molar root dentin.

It is possible that chemical differences between different types of teeth may also be significant. SydneyZax et al. (12) have reported that unerupted mature bovine enamel was slightly higher in carbonate concentration than human enamel, indicating that bovine teeth may be more susceptible to acid attack due to the variations in the hydroxyapatite lattice.

In order to establish a meaningful comparison of human and bovine dentin, this study compared the diameter and the number of tubules per square millimeter between both substrates. The tested hypothesis was that bovine teeth are an acceptable substrate for use in in vitro testing of dental adhesive and restorative materials due to their similar morphology to human teeth.

\section{MATERIAL AND METHODS}

The study used 10 non-carious human molars extracted for orthodontic reasons from young patients (18-25 years old) after the approval by the Research
Ethics Committee of Piracicaba Dental School (Protocol \#106/2004) and 10 bovine incisors obtained from a slaughterhouse. The teeth periodontal ligament remnants removed with a 5-6 Gracey curette and were stored in $0.9 \%$ sodium hypochlorite for a maximum period of 90 days. The roots were removed using a saw (Model 650, South Bay Technology) and the crowns were ground with a high-speed handpiece using FG4138, FG4138F and FG4138FF burs (MKS, São Paulo, SP, Brazil) to obtain 3 sections of dentin at different depths (superficial, middle and deep dentin) having a tubular orientation, perpendicular to the observed surfaces. The specimens were etched with $37 \%$ phosphoric acid during 20 and 40 $\mathrm{s}$ for human and bovine dentin, respectively, to open the dentinal tubule entrances, and were then rinsed in running water and ultrasonically cleaned. Then, the specimens were sputter-coated with gold (SCD-050, Balzers, Liechtenstein) and examined with a scanning electron microscope (JSM 5600 LV; JEOL, Tokyo, Japan). Nine SEM micrographs were recorded for each dentin sample, 3 random SEM micrographs being recorded for each dentin depth. On each SEM micrograph, 5 random tubule diameters were measured (SEM software) and the number of tubules per unit area was counted (Fig. 1). The mean tubule diameters from each specimen and the number of tubules per unit area were analyzed statistically by ANOVA and Tukey's test $(\alpha=0.05)$.

\section{RESULTS}

Table 1 shows the dentin tubule diameters for

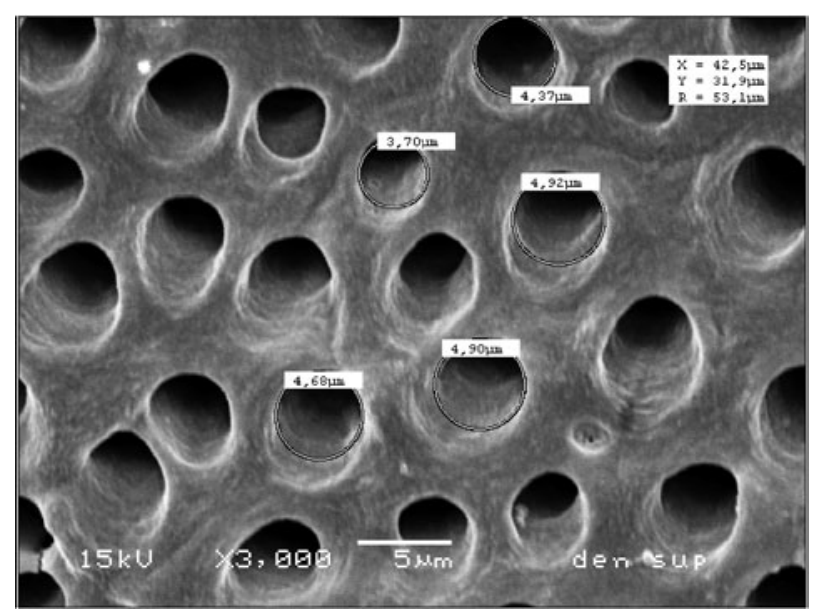

Figure 1. SEM micrograph showing dentinal tubules and total area measured under in bovine dentin. 
human and bovine teeth in superficial, middle and deep dentin. In bovine teeth, superficial dentin $(4.21 \mu \mathrm{m})$ and middle dentin $(3.98 \mu \mathrm{m})$ had a significantly greater $(\mathrm{p}<0.05)$ diameter than deep dentin $(3.14 \mu \mathrm{m})$ tubules. In human teeth, superficial dentin tubule diameter $(2.42$ $\mu \mathrm{m})$ was significantly smaller $(\mathrm{p}<0.05)$ than deep dentin $(2.99 \mu \mathrm{m})$ and middle dentin $(2.94 \mu \mathrm{m})$ tubule diameters, which did not differ significantly from each other $(p>0.05)$. The diameter of dentin tubules was statistically greater $(\mathrm{p}<0.05)$ in bovine superficial $(4.21 \mu \mathrm{m})$ and middle $(3.98 \mu \mathrm{m})$ dentin than in human superficial $(2.42 \mu \mathrm{m})$ and middle $(2.94 \mu \mathrm{m})$ dentin, respectively. The bovine deep dentin $(3.14 \mu \mathrm{m})$ and human deep dentin $(2.99 \mu \mathrm{m})$ tubule diameters did not differ significantly.

Table 2 shows the density of dentinal tubules per square millimeter for the 3 depths of bovine and human dentin. In bovine teeth, the number of tubules per square millimeter in the superficial dentin was smaller than in the middle and deep dentin, which, in turn, differed significantly $(p<0.05)$ from each other. In human teeth, the number of tubules in the deep dentin was larger than in the middle and superficial dentin, which, in turn, differed significantly $(p<0.05)$ from each other. The concentration of tubules in human teeth was

Table 1. Comparison of dentinal tubule diameter $(\mu \mathrm{m})$.

\begin{tabular}{lll}
\hline Depth & Human teeth & Bovine teeth \\
\hline Superficial dentin & $2.42(0.56)^{\mathrm{bA}}$ & $4.21(0.44)^{\mathrm{aB}}$ \\
Middle dentin & $2.94(0.38)^{\mathrm{aA}}$ & $3.98(0.26)^{\mathrm{aB}}$ \\
Deep dentin & $2.99(0.44)^{\mathrm{aA}}$ & $3.14(0.41)^{\mathrm{bA}}$ \\
\hline
\end{tabular}

*Means followed by the same lowercase letters in columns and uppercase letter row are not significantly different $(p>0.05)$. Values in parentheses are standard deviations.

Table 2. Comparison of dentinal tubule density (tubules $/ \mathrm{mm}^{2}$ ).

\begin{tabular}{lcc}
\hline Depth & Human teeth & Bovine teeth \\
\hline Superficial dentin & $15,385(5,309)^{\mathrm{aA}}$ & $11,530(2,875)^{\mathrm{aB}}$ \\
Middle dentin $^{\mathrm{aB}}$ & $21,006(7,473)^{\mathrm{bA}}$ & $15,414(5,289)^{\mathrm{bB}}$ \\
Deep dentin $^{\mathrm{bB}}$ & $30,595(12,247)^{\mathrm{cA}}$ & $20,948(4,558)^{\mathrm{cB}}$ \\
\hline
\end{tabular}

*Means followed by the same lowercase letters in columns and uppercase letter row are not significantly different $(p>0.05)$. Values in parentheses are standard deviations. significantly greater $(p<0.05)$ than in bovine teeth at all dentin depths.

\section{DISCUSSION}

Human teeth must be considered the most appropriate hard tissue substrate for in situ studies from the perspective of clinical relevance (1). However, human teeth are of a highly variable composition due to genetic influences, environmental conditions and age. Bovine enamel has a more uniform composition than human enamel, and thus provides a less variable substrate for research purposes. However, bovine enamel is more porous and demineralizes faster (1) than human enamel. According to Edmunds et al. (13), the considerable variability in structure of human surface enamel may result in variation in caries susceptibility among individuals. Furthermore, bovine and swine teeth have been shown to have lower tubule density ratio value than human teeth (14). This confirms in an indirect way that the mineral composition of human and bovine teeth is different.

Among the different groups of teeth, incisors are preferred for in vitro studies when using bovine teeth due to their size and relatively flat surface (1). When using human teeth, it is difficult to obtain non-carious incisors and therefore molars are preferred.

In this study, a different structure in the bovine dentinal tubules was found compared to human dentin. This anomalous structure found in many of the specimens analyzed has the appearance of a tubule conjunction,

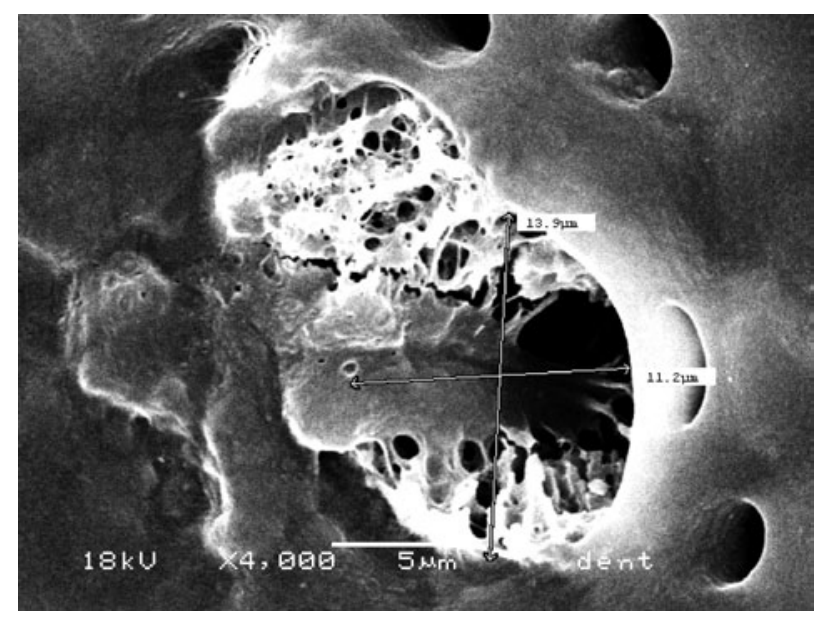

Figure 2. SEM micrograph showing a conglomerate of dentinal tubules in a bovine tooth $(\times 4,000$ magnification $)$. 
resulting in a wider tubular structure (Fig. 2). The large crystals grains and the lattice defects found in bovine enamel have been described as the result of the rapid development of bovine teeth during tooth formation before and after eruption (15). This may happen with dentin also and may explain the origin of these bovine dentin tubule conglomerates.

McCabe and Rusby (16) showed the existence of lower values of bond strength on human dentin near to the pulp when compared to superficial dentin, while Moura (17) found different morphological aspects of the bonding interface on MOD restorations. Öilo and Olsson (18) showed that a higher bond strength to dentin from a buccal area than from an occlusal area is obtained with human third molars. Hence, there is much circumstantial evidence of a variation of dentin structure with depths. The present study showed that the tubular diameter in superficial and middle bovine dentin was significantly greater than the human superficial and middle dentin. In deep dentin, no difference was found between bovine and human dentin tubule diameter. The values obtained indicate that the morphology of dentinal tubules is different for both substrates, with human dentin having dentin tubules with larger diameter near the pulp and smaller diameter near the cementoenamel junction. In bovine dentin, the opposite occurs, larger tubule diameter is observed near the cementoenamel junction and smaller tubule diameter is observed near the pulp. This finding agrees with those of Dutra-Correa et al. (19), which found that the cone-shape of bovine dentinal tubule possesses its larger base at the outer end, different human dentin, which presents larger base is at the pulpal end.

When the number of tubules per square millimeter was compared, human dentin had a greater concentration of tubules compared to bovine dentin, independent of the region depth. In the same substrate group (human or bovine), deep dentin had a greater concentration of tubules than middle or superficial dentin. The differences observed in the present study may explain the different behaviors of human and bovine substrates when using different adhesive materials. For example, Lopes et al. (20) showed significant differences between human and bovine dentin for shear bond strength when using the same etch-and-rinse adhesive system.

The null hypothesis must be rejected since morphological differences were found between human and bovine dentin tubule structure, which may influence adhesive test results. In conclusion, the presence of larger diameter conglomerate tubules in bovine dentin may also be a significant factor to influence the adhesion process. Therefore, it is necessary to be careful when using bovine dentin for the evaluation of adhesives.

\section{RESUMO}

Este estudo comparou a dimensão e a distribuição tubular da dentina humana e bovina. Dez molares humanos e 10 incisivos bovinos foram desgastados com alta rotação para se obter 3 secções de diferentes profundidades de dentina (superficial, média e profunda). As amostras foram cobertas com ouro em um metalizador para a observavação em MEV. Três micrografias foram tiradas aleatoriamente para cada profundidade de dentina. O número de túbulos foi contado e o diâmetro de 5 túbulos selecionados aleatoriamente foi medido para cada micrografia. Os resultados foram submetidos à análise de variância e ao teste de Tukey $(\alpha=0.05)$. Em dente bovino, a dentina superficial $(4,21$ $\mu \mathrm{m})$ e a dentina média $(3,98 \mu \mathrm{m})$ apresentaram diâmetro estatisticamente superior $(p<0,05)$ à dentina profunda $(3,14 \mu \mathrm{m})$. Em dente humano, o diâmetro dos túbulos da dentina superficial $(2,42 \mu \mathrm{m})$ mostrou-se significativamente menor que a dentina profunda $(2,99 \mu \mathrm{m})$ e média, $(2,94 \mu \mathrm{m})$ as quais não diferiram entre si. O numero de túbulos por $\mathrm{mm}^{2}$, independente da região, foi significativamente maior para a dentina humana $(22,329)$ que para dentina bovina $(15,964)$. Houve uma clara diferença na estrutura tubular e morfológica entre dentina humana e bovina.

\section{ACKNOWLEDGEMENTS}

The authors are grateful to the Brazilian funding agency CAPES for financial support (BEX: 3427/04-8).

\section{REFERENCES}

1. Mellberg JR. Hard-tissue substrates for evaluation of cariogenic and anti-cariogenic activity in situ. J Dent Res 1992;71:913-919.

2. Pearce EI. A microradiographic and chemical comparison of in vitro systems for the simulation of incipient caries in abraded bovine enamel. J Dent Res 1983;62:969-974.

3. Arends J, Schuthof J, Jongebloed WG. Lesion depth and microhardness indentations on artificial white spot lesions. Caries Res 1980;14:190-195.

4. Reis AF, Giannini M, Kavaguchi A, Soares CJ, Line SR. Comparison of microtensile bond strength to enamel and dentin of human, bovine, and porcine teeth. J Adhes Dent 2004;6:117-121.

5. Mellberg JR, Loertscher KL. Comparison of in vitro fluoride uptake by human and bovine enamel from acidulated phosphatefluoride solutions. J Dent Res 1974;53:64-67.

6. Camargo MA, Marques MM, de Cara AA. Morphological analysis of human and bovine dentine by scanning electron microscope investigation. Arch Oral Biol 2008;53:105-108.

7. Reeves GW, Fitchie JG, Hembree JH Jr., Puckett AD. Microleakage of new dentin bonding systems using human and bovine teeth. Oper Dent 1995;20:230-235.

8. Kruzic JJ, Nalla RK, Kinney JH, Ritchie RO. Mechanistic aspects of in vitro fatigue-crack growth in dentin. Biomaterials 2005;26:1195-1204. 
9. Marshall GW Jr., Marshall SJ, Kinney JH, Balooch M. The dentin substrate: structure and properties related to bonding. J Dent 1997;25:441-458.

10. Schilke R, Lisson JA, Bauss O, Geurtsen W. Comparison of the number and diameter of dentinal tubules in human and bovine dentine by scanning electron microscopic investigation. Arch Oral Biol 2000;45:355-361.

11. Tagami J, Tao L, Pashley DH. Correlation among dentin depth, permeability, and bond strength of adhesive resins. Dent Mater 1990;6:45-50.

12. Sydney-Zax M, Mayer I, Deutsch D. Carbonate content in developing human and bovine enamel. J Dent Res 1991;70:913-916.

13. Edmunds DH, Whittaker DK, Green RM. Suitability of human, bovine, equine, and ovine tooth enamel for studies of artificial bacterial carious lesions. Caries Res 1988;22:327-336.

14. Fonseca RB, Haiter-Neto F, Fernandes-Neto AJ, Barbosa GA, Soares CJ. Radiodensity of enamel and dentin of human, bovine and swine teeth. Arch Oral Biol 2004;49:919-922.
15. Moriwaki Y, Kani T, Kozatani T, Tsutsumi S, Shimode N, Yamaga $\mathrm{R}$. The crystallinity change of bovine enamel during maturation. Jpn J Dent Mat 1968;9:78-85.

16. McCabe JF, Rusby S. Dentine bonding agents-characteristic bond strength as a function of dentine depth. J Dent 1992;20:225-230.

17. Moura SK, Santos JF, Ballester RY. Morphological characterization of the tooth/adhesive interface. Braz Dent J 2006;17:179-185.

18. Oilo G, Olsson S. Tensile bond strength of dentin adhesives: a comparison of materials and methods. Dent Mater 1990;6:138144.

19. Dutra-Correa M, Anauate-Netto C, Arana-Chavez VE. Density and diameter of dentinal tubules in etched and non-etched bovine dentine examined by scanning electron microscopy. Arch Oral Biol 2007;52:850-855.

20. Lopes MB, Sinhoreti MA, Correr Sobrinho L, Consani S. Comparative study of the dental substrate used in shear bond strength tests. Braz Oral Res 2003;17:171-175

Accepted October 16, 2009 